Sains Malaysiana 50(6)(2021): 1563-1575

http://doi.org/10.17576/jsm-2021-5006-05

\title{
Kesan Suhu dan Bahan Tambah Abu Terbang terhadap Pencirian Mekanik Bata daripada Sisa Rawatan Air Mentah
}

(Effects of Temperature and Fly Ash Additive on Mechanical Characteristics of Brick from Raw Water Treatment Sludge)

\section{Zulfahmi Ali RaHmaN*, AKRimi Maswa Othman, WAN MOHD. RAZI IDRIS \& TUKimat LiHAN}

\begin{abstract}
ABSTRAK
Penggunaan semula sisa dalam pembangunan bata giat diusahakan dan beberapa pengubahsuaian dilakukan bagi menghasilkan produk bata yang berkualiti baik dan selamat. Suhu merupakan antara faktor yang mempengaruhi cirian mekanik bata. Oleh itu, objektif kajian ini adalah untuk melihat pengaruh suhu dan abu terbang (RAM) terhadap sifat mekanik bata yang dihasilkan daripada campuran sisa rawatan air mentah (RAM). Dua jenis sampel bata disediakan melibatkan bata 100\% sisa RAM (RAM100) dan bata campuran 80\% sisa RAM dan 20\% AT (RAM80). Kedua-dua jenis sampel dikenakan suhu pembakaran berbeza (tanpa bakar, $500{ }^{\circ} \mathrm{C}, 700{ }^{\circ} \mathrm{C}$ ) selama tiga jam. Ujian larutresap turut dilakukan bagi mengenal pasti kepekatan logam berat yang hadir dalam bata. Pencirian mekanik bagi penyusutan linear menunjukkan peningkatan dengan pertambahan suhu. Kehadiran sisa AT meningkatkan nilai penyusutan linear yang lebih tinggi berbanding bata berasaskan RAM (RAM100) apabila suhu meningkat daripada 350 kepada $700{ }^{\circ} \mathrm{C}$. Nilai ketumpatan kedua-dua jenis bata turut menyusut dengan peningkatan suhu namun meningkat semula pada suhu yang lebih tinggi $\left(700^{\circ} \mathrm{C}\right)$. Kedua-dua jenis bata juga menunjukkan peningkatan penyerapan air dengan peningkatan suhu. Kehadiran AT turut mengurangkan nilai serapan air berbanding bata RAM100. Kekuatan mampatan bata meningkat dengan peningkatan suhu dan bata RAM100 menunjukkan corak peratus peningkatan yang ketara berbanding bata RAM80. Namun, daripada perspektif peratusan, kehadiran AT menunjukkan peratusan pertambahan kekuatan mampatan yang ketara berbanding bata RAM100. Daripada hasil ujian larutresap dan cirian mekanik yang dilakukan, sisa rawatan air dan abu terbang berpotensi digunakan sebagai bahan asas dalam pembangunan bata dan beberapa pengubahsuaian diperlukan bagi mencapai piawaian yang ditetapkan sebagai bahan binaan alternatif.
\end{abstract}

Kata kunci: Abu terbang; bata; kekuatan mampatan; larutresap; sisa rawatan air mentah

\section{ABSTRACT}

Re-utilization of wastes in brick development has been progressively carried out and several modifications have been done to produce brick with good quality and safe. Temperature is among the factors that control the mechanical properties of brick. Therefore, the objective of this study was to investigate the effects of temperature and fly ash on mechanical properties of brick from raw water treatment sludge (RAM). Two types of brick samples were prepared included brick with 100\% of RAM (RAM100) and brick from mixture of $80 \%$ of RAM and 20\% AT (RAM80). Both samples were treated with different firing temperatures (unfired, $500{ }^{\circ} \mathrm{C}, 700{ }^{\circ} \mathrm{C}$ ) for $3 \mathrm{~h}$. Leaching test was also conducted to identify the concentration of the present heavy metals in the brick. The mechanical characteristic of linear shrinkage showed an increasing trend with the increase in temperature. The presence of AT increased the value of linear shrinkage compared to brick with RAM base (RRAM100) as the temperatures were increased from 350 to $700{ }^{\circ} \mathrm{C}$. The density of both bricks also decreased with increasing temperature, however, increased back at higher temperature $\left(700^{\circ} \mathrm{C}\right)$. Both bricks showed increased in water absorption with increased temperatures. Presence of AT also decreased the value of water absorption when compared with RAM100 brick. The compressive strength of brick increased with increasing temperature and RAM100 brick showed apparently higher percentage than RAM80 brick. Role of AT also significantly increased the percentage of compressive strength compared to that brick of RAM100. Based on the results of leaching tests and mechanical characteristics, the raw water treatment sludge and fly ash are potentially re-utilized as base material in development of brick and several modifications are required to achieve the regulated standard as alternative construction material.

Keywords: Brick; compressive strength; fly ash; leaching; raw water treatment sludge 


\section{PENDAHULUAN}

Pembangunan infrastruktur yang pesat sejajar dengan pertambahan penduduk yang meningkat setiap tahun. Menurut Jabatan Perangkaan Negara, penduduk Malaysia berjumlah 32.4 juta pada tahun 2018 telah meningkat sebanyak 1.15 kepada $32.6 \%$ pada tahun 2019. Kadar peningkatan ini lebih tinggi berbanding perubahan penduduk pada tahun 2015 dan 2016 sebanyak 0.5\% (Jabatan Perangkaan Malaysia 2019). Pola ini meningkatkan keperluan sumber air bersih dan tenaga, di samping keperluan bahan binaan bagi pembangunan infrastruktur. Bata dan simen merupakan antara bahan utama dalam sektor pembinaan. Penghasilan kedua-dua bahan binaan ini melibatkan sumber semula jadi yang terhad dan melibatkan penggunaan tenaga terma yang tinggi di samping pembebasan gas karbon dioksida $\left(\mathrm{CO}_{2}\right)$ ke atmosfera (Ling \& Teo 2011; Madurwar et al. 2013). Kajian berkaitan penggunaan bahan sumber lain yang berpotensi giat dijalankan sebagai alternatif kepada sumber bersifat terhad yang melibatkan penggunaan semula sisa-sisa daripada industri. Keadaan ini dapat menjamin kos pengeluaran yang lebih murah dan membantu meminimumkan masalah pelupusan sisa tersebut seterusnya memelihara alam sekitar (Ali Rahman et al. 2019).

Abu terbang (AT) dan sisa rawatan air mentah (RAM) merupakan sisa berpotensi digunakan dalam penghasilan bata alternatif (Anyakora 2013; Chiang et al. 2009; Hegazy et al. 2012; Krishnan \& Jewaratnam 2017). Sisa AT merupakan sisa sampingan yang dihasilkan daripada loji janakuasa elektrik berasaskan pembakaran arang batu. Ia mengandungi silika dioksida $\left(\mathrm{SiO}_{2}\right)$, oksida aluminium, ferum dan kalsium sebagai komposisi utama. Sisa AT berpotensi memperbaiki cirian fizikokimia tanah jelekit (Prabakar et al. 2004; Puppala \& Musenda 2000). Sisa RAM pula merupakan hasil daripada proses penggumpalan dalam perawatan air mentah menggunakan agen penggumpal yang terdiri daripada aluminium silikat (alum) dan/atau poli-aluminium klorida (PAC) yang akan bertindak balas dengan air menghasilkan aluminium hidroksida dalam bentuk zarahan terampai dan koloid (Joshi \& Shrivastava 2011; Sanga et al. 2018). Kemudian sisa ini dialirkan ke lagun pengeringan separa sebelum dipindahkan ke tapak khusus bagi proses pengeringan dan penstabilan lanjut. Kedua-dua sisa ini mengandungi komposisi utama yang dimiliki oleh lempung (Anyakora et al. 2012; Tantawy \& Mohamed 2017). Sisa AT yang bersifat pozolanik boleh bertindak balas dengan $\mathrm{Ca}(\mathrm{OH})_{2}$ daripada hidrasi simen untuk membentuk C-S-H (Wang et al. 1994).

Beberapa kajian menunjukkan penggunaan semula sisa RAM dan AT dalam pembikinan bata alternatif (Chiang et al. 2009; Fungaro \& Silva 2014; Hegazy et al.
2012; Krishnan \& Jewaratnam 2017). Cirian pengecutan linear, serapan air dan kekuatan mampatan antara parameter fizikal utama dalam piawaian kualiti sesuatu bata. Kesan kehilangan air dikaitkan dengan pengecutan fraksi lempung dalam bahan asas bata yang digunakan. Kehadiran kandungan lempung yang rendah dengan indeks keplakstikan, $I_{p}$ kurang 20\% mengakibatkan pengecutan kering meningkat secara sekata dengan peningkatan kandungan lempung namun meningkat dengan ketara apabila $I_{p}$ berjulat antara $25-30 \%$ (Riza et al. 2010). Pengecutan linear berlaku semasa proses pengeringan dan pembakaran bata akibat pelepasan air daripada bata (air bebas dan terikat). Penggunaan suhu dan tempoh pembakaran menyebabkan perubahan nilai pengecutan linear sehingga mempengaruhi kualiti bata (Johari et al. 2010; Karaman et al. 2006). Pengecutan yang tinggi semasa pengeringan dan pembakaran boleh menyebabkan kerosakan bata. Mageed et al. (2011) mendapati bahawa serapan air meningkat dan sebaliknya bagi kekuatan mekanik dengan penambahan sisa RAM terhadap bata liat.

Kekuatan mampatan sesuatu bata yang dihasilkan sangat dipengaruhi oleh suhu semasa proses pembakaran bata tersebut (Chen et al. 2011; Xu et al. 2005; Zhang 2013). Penggunaan suhu dan tempoh pembakaran yang berbeza memberi kesan kepada kualiti bata di samping impak kos dan produktivi pengeluaran (Presertsan \& Theppaya 1995). Kajian ini bertujuan untuk menilai pengaruh suhu pembakaran dan bahan tambah sisi AT terhadap bata daripada campuran sisa RAM dan AT pada nisbah tertentu. Sampel bata yang disediakan kemudian dibakar pada suhu berbeza bagi melihat kesan suhu terhadap sifat mekanik bata-bata tersebut. Sampel bata tanpa bakar (kawalan) turut disediakan sebagai perbandingan dalam kajian ini.

\section{BAHAN DAN KAEDAH}

\section{BAHAN ASAS}

Sisa rawatan air mentah (RAM) diperoleh daripada loji perawatan air mentah di Ijok, Selangor. Sampel ini didapati dalam keadaan separa kering dan diletakkan ke dalam bekas plastik bertutup rapat. Seterusnya sampel ini dikeringkan di makmal pada suhu bilik selama beberapa hari. Pembentukan agregatan dihancurkan secara manual sebelum disaring melalui pengayak bersaiz $2 \mathrm{~mm}$. Manakala sampel sisa abu terbang (AT) diambil daripada janakuasa elektrik Sultan Salahuddin Abdul Aziz, Kapar Selangor. Sampel AT digunakan sebagai bahan tambah kepada bahan asas sisa RAM dalam pembuatan bata. Pada peringkat awal, pencirian asas kedua-dua sampel sisa ditentukan dan hasil pencirian ini ditunjukkan oleh Jadual 1. 
JADUAL 1. Hasil penentuan cirian asas bagi sampel RAM dan AT

\begin{tabular}{|c|c|c|c|c|}
\hline \multirow{2}{*}{ Parameter } & \multirow{2}{*}{$\begin{array}{l}\text { Sisa rawatan air } \\
\quad \text { (SRA) }\end{array}$} & \multicolumn{3}{|c|}{ Abu terbang (AT) } \\
\hline & & Kawalan & $500^{\circ} \mathrm{C}$ & $700^{\circ} \mathrm{C}$ \\
\hline Nilai pH & 4.44 & 8.44 & 8.01 & 8.46 \\
\hline Graviti tentu & 2.21 & 2.11 & 2.12 & 2.13 \\
\hline Kandungan bahan organik (\%) & 6.80 & 1.30 & 0.11 & 0.02 \\
\hline \multicolumn{5}{|l|}{ Taburan saiz zarah: } \\
\hline Lempung (\%) & 29.85 & 9.21 & 9.71 & 11.06 \\
\hline Lodak $(\%)$ & 46.45 & 79.84 & 77.63 & 75.24 \\
\hline Pasir (\%) & 23.69 & 10.94 & 12.66 & 13.70 \\
\hline Luas permukaan tentu $\left(\mathrm{m}^{2} / \mathbf{g}\right)$ & 35.68 & 42.00 & 24.5 & 35.04 \\
\hline \multicolumn{5}{|l|}{ Had Atterberg: } \\
\hline Had cecair, $w_{L}(\%)$ & 61.27 & 27.87 & 24.18 & 26.16 \\
\hline Had plastik, $w_{P}(\%)$ & 50.11 & 26.08 & 21.84 & 24.64 \\
\hline Indeks keplastikan, $I_{P}(\%)$ & 11.16 & 1.79 & 2.34 & 1.52 \\
\hline Pembelauan Sinar-X (XRD) & $\begin{array}{c}\text { Kaolinit, }\left(\mathrm{Al}_{2} \mathrm{SO}_{4} \mathrm{H}(\mathrm{OH})_{4}\right) \\
\text { Silika, }\left(\mathrm{SiO}_{2}\right)\end{array}$ & \multicolumn{3}{|c|}{$\begin{array}{c}\text { Mulit, }\left(3 \mathrm{Al}_{2} \mathrm{O}_{3} \cdot 2 \mathrm{SiO}_{2}\right) \\
\text { Silika, }\left(\mathrm{SiO}_{2}\right)\end{array}$} \\
\hline Pendaflour Sinar-X (XRF) & $\mathrm{SiO}_{2}, \mathrm{Al}_{2} \mathrm{O}_{3}, \mathrm{Fe}_{2} \mathrm{O}_{3}, \mathrm{~K}_{2} \mathrm{O}$ & \multicolumn{3}{|c|}{$\mathrm{SiO}_{2}, \mathrm{Al}_{2} \mathrm{O}_{3}, \mathrm{Fe}_{2} \mathrm{O}_{3}, \mathrm{CaO}$} \\
\hline
\end{tabular}

Umumnya, pH sisa RAM adalah berasid dengan pH 4.44 manakala sisa AT pula adalah jenis alkali dengan julat $\mathrm{pH} 8.01$ hingga $\mathrm{pH}$ 8.46. Nilai $\mathrm{pH}$ sisa AT tidak banyak berubah pada suhu rawatan yang berbeza. Kandungan organik yang rendah bagi sisa AT dikaitkan oleh proses pembakaran yang bersuhu tinggi yang dialami oleh sisa ini. Taburan saiz zarah pula menunjukkan kehadiran fraksi lodak yang tinggi bagi sisa RAM manakala sisa AT menunjukkan lodak merupakan fraksi yang lebih dominan berbanding fraksi pasir dan lempung (Rajah 1(a)). Luas permukaan tentu bagi sisa RAM adalah rendah berbanding sisa AT, masing-masing 35.6 dan 42 $\mathrm{m}^{2} \mathrm{~g}^{-1}$. Sisa RAM menunjukkan indeks keplastikan, $I_{P}$ lebih tinggi berbanding AT dikaitkan oleh kehadiran fraksi saiz lempung yang rendah di dalam sisa AT (Jadual 1). Kesan suhu tidak memberi kesan kepada nilai $I_{P}$ sisa AT. Tanah lempung dengan had cecair, $w_{L}$ yang sangat tinggi mudah terdedah kepada kekeringan dan keretakan manakala nilai $w_{L}$ dan $I_{P}$ yang sangat rendah pula menyebabkan pembentukan liang makro yang mengakibatkan ikatan lemah antara zarah (Bajaj et al. 2013; Daniel 1987). Imej SEM menunjukkan kehadiran mineral liat jenis kaolinit
$\left(\left(\mathrm{Al}_{2} \mathrm{SO}_{4} \mathrm{H}(\mathrm{OH})_{4}\right)\right.$ yang dominan dicirikan oleh sifat berkeping dan juga mineral kuarza (Rajah 1(b)). Rajah 1(c) pula menunjukkan sisa AT yang dicampurkan ke dalam sisa RAM.

\section{PENYEDIAAN SAMPEL}

Pencirian mekanik dilakukan ke atas sampel bata dengan dimensi piawai iaitu $215 \times 102.5 \times 65 \mathrm{~mm}(\mathrm{MS} 76$ : 1972). Penyediaan sampel bata melibatkan bata dengan campuran sisa RAM dan sisa AT dengan rawatan suhu yang berbeza. Berdasarkan pemerhatian oleh Ali Rahman et al. (2016), sisa AT mengakibatkan penyusutan nilai serapan air sebaliknya meningkatkan ketumpatan dan kekuatan mampatan bata. Pengaruh suhu juga turut memperbaiki kekuatan mekanik bata campuran sisa RAM dan abu sekam padi yang dirawat pada 300 dan 500 ${ }^{\circ} \mathrm{C}$ (Ali Rahman et al. 2019). Dua set sampel bata telah disediakan melibatkan bata dengan kandungan (a) 100\% RAM dan (b) $80 \%$ RAM (terdiri daripada $80 \%$ sisa RAM dan $20 \%$ sisa AT) dengan masing-masing dilabelkan sebagai RAM100 dan RAM80. Peringkat awal penyediaan 
melibatkan campuran kering kedua-dua sisa sebelum air suling ditambah perlahan-lahan berjulat antara 950 dan $1000 \mathrm{~mL}$ bergantung kepada kandungan sisa AT yang digunakan. Kemudian, campuran digaul sekata sehingga menghasilkan buburan dan dituangkan ke dalam acuan. Sampel dituangkan perlahan-lahan ke dalam acuan di atas alat penggetar bagi membebaskan udara terperangkap. Sampel bata dibiarkan selama 4-5 hari sebelum dikeluarkan daripada acuan dan dibiarkan untuk pengeringan lanjut selama 3 hari sebelum dimasukkan ke dalam relau. Sampel bata dipanaskan pada suhu 350 dan $700{ }^{\circ} \mathrm{C}$ selama 3 jam. Terdapat sampel bata yang dibiarkan mengalami pengeringan berterusan (bata normal i.e. TB-tanpa bakar) pada suhu bilik selama 14 hari bagi tujuan perbandingan.

\section{UJIAN LARUTRESAP}

Pembangunan bata alternatif berasaskan kepada penggunaan semula sisa daripada proses perawatan air mentah dikhuatiri menyebabkan pelepasan logam berat seperti aluminium (Al), arsenik (As), cadmium $(\mathrm{Cd})$, kromium $(\mathrm{Cr})$, kuprum $(\mathrm{Cu})$, plumbum $(\mathrm{Pb})$, nikel $(\mathrm{Ni})$, zink ( $\mathrm{Zn})$ dan ferum (Fe). Kaedah ini merupakan ubahsuaian daripada ujian larutresap statik (SLT) digunakan bagi menentukan kesan larutresapan bagi bata yang dihasilkan dalam jangka masa panjang (ANSI/AN16.1-2003). Ketulan kecil sampel bata daripada setiap jenis sampel bata (bata tanpa bakar, sampel bata dibakar pada suhu 350 dan $700{ }^{\circ} \mathrm{C}$ ) yang telah ditentukan jisim diletakkan di dalam bekas berisi cecair resapan yang terdiri daripada air hujan. Setiap sampel dibiarkan selama 1, 3, $5,7,14,30$ dan 60 hari sebelum sampel cecair larutresap diambil untuk penentuan kepekatan logam. Sampel larutan yang disediakan digunakan bagi analisis penentuan kepekatan logam berat menggunakan spektrometri jisim plasma gandingan aruhan (ICPMS) di makmal.

(a)

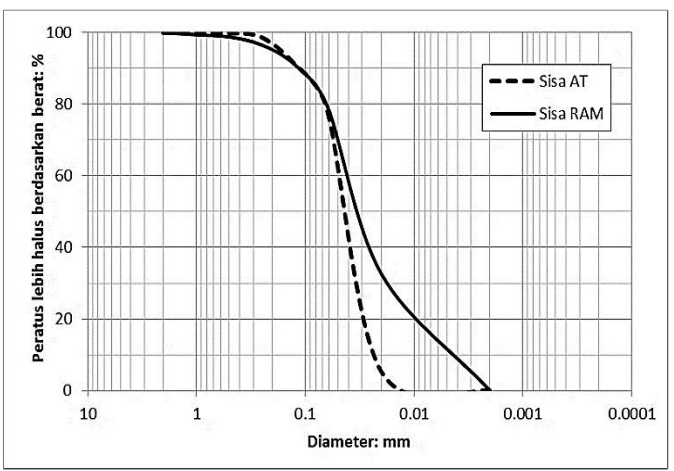

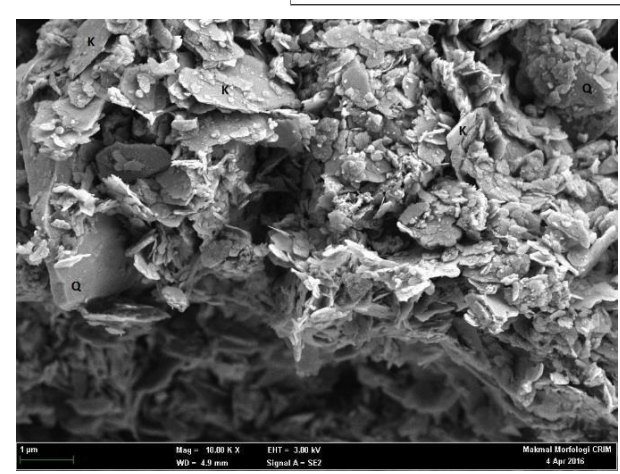

(b)

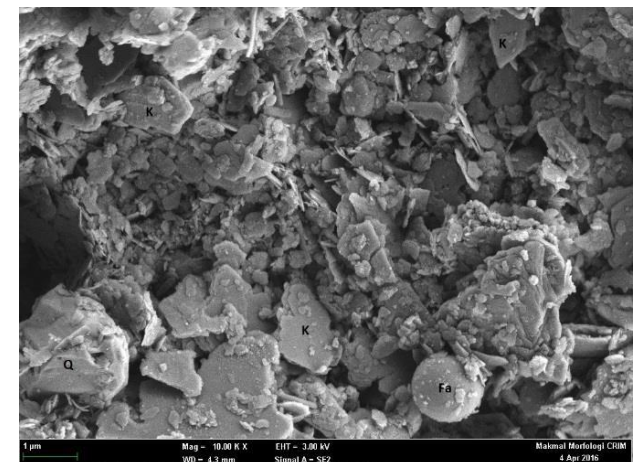

(c)

RAJAH 1. (a) Lengkuk taburan saiz zarah sisa yang digunakan dan imej SEM sampel bata, (b) RAM100 dan (c) RAM80 (K-kaolinit; Fa- abu terbang; Q-kuarza) 


\section{PENCIRIAN MEKANIK BATA}

Penentuan parameter mekanik bagi sampel bata dilakukan berdasarkan penyusutan linear, ketumpatan, serapan air dan kekuatan mampatan (UCS). Pencirian bagi serapan air dan kekuatan mampatan dilakukan berdasarkan piawaian BS 3921: British Standard Specifications for Clay Bricks (1985). Manakala penentuan pengecutan linear, $L$ yang diaplikasikan daripada toleransi dimensi. Kesan pengeringan dan seterusnya proses pembakaran bata mengakibatkan penyusutan menyeluruh dimensi akhir bata. Selepas proses pembakaran, sampel dibiarkan menyejuk semalaman di dalam relau (Karaman et al. 2006). Pengukuran ini melibatkan sukatan dimensi panjang, lebar dan tinggi dalam barisan mendatar, menegak dan menyisi bata melibatkan 12 unit sampel bata manakala ukuran dimensi setiap individu bata pula melibatkan 6 unit sampel bata turut diukur (BS 3921: 1985). Angkup venier dan pita pengukur digunakan untuk mengukur dimensi sampel. Pengecutan linear, $L$ dihitung berasaskan (1) seperti berikut:

$$
\text { Pengecutan linear, } L=\frac{L_{o}-L_{i}}{L_{o}} \times 100 \%
$$

dengan $L_{o}$ ialah ukuran asal sebelum pengeringan atau pembakaran, unit $\mathrm{mm}$; $L_{i}$ ialah ukuran selepas proses pengeringan atau pembakaran, unit mm. Berdasarkan nilai dimensi yang diukur, perubahan isipadu bata selepas pembakaran, $\Delta V$ ditentukan berdasarkan perbezaan isipadu asal, $V_{o}$ dan isipadu akhir, $V_{i}$ seperti (2) berikut:

$$
\text { Perbezaan isipadu, } \Delta V=\frac{\left(V_{o}-V_{i}\right)}{V_{o}} \times 100 \%
$$

Penentuan ketumpatan sampel bata dilakukan mengikut kaedah AS/NSS 4456.8:1997. Setiap sampel bata ditandakan dan jisim kering ditentukan, $m_{d}$. Sampel bata direndam di dalam air selama 2 jam. Kemudian sampel bata dikeluarkan dari tangki rendaman dan dibiarkan selama 1 minit dan lebihan air di permukaan bata dilap sebelum jisim basah, $m$ ditimbang. Sampel bata dipindahkan ke penimbang dalam air dan jisim bata terendam, $m_{2}$ ditentukan. Langkah ini diulang bagi keenam-enam sampel bata. Prinsip Archimedes digunakan dalam penentuan ketumpatan bata berdasarkan (3) dan (4) berikut:

$$
\text { Isipadu, } V=\left(m_{1}-m_{2}\right) \times 1000
$$

$$
\text { Ketumpatan, } D_{s}=\left(\frac{m_{d}}{V}\right) \times 100
$$

Parameter serapan air sampel bata pula ditentukan dengan merendam sampel ke dalam air selama 24 jam (MS 76: 1972). Peringkat awal, sampel bata ditimbang, $m_{d}$ sebelum bata dimasukkan ke dalam tangki berisi air selama 24 jam. Kemudian sampel-sampel bata ditimbang semula untuk menetukan jisim tepu, $m_{\text {sat }}$. Nilai serapan air ditentukan melalui (5) berikut:

$$
\text { Serapan air, } W_{\text {sat }}=\left(\frac{m_{\text {sat }}-m_{d}}{m_{d}}\right) \times 100
$$

Parameter kekuatan mampatan bata pula ditentukan dengan melakukan ujian mampatan terhadap bata sehingga bata mengalami kegagalan. Bata daripada ujian serapan air digunakan semula untuk penentuan parameter ini. Kaedah ini dijalankan dengan meletakkan bata yang diapit dengan sekeping papan lapis bagi mengelakkan geseran akibat daripada ketidaseragaman permukaan bata. Dimensi keseluruhan papan lapis perlu $10 \mathrm{~mm}$ lebih besar berbanding saiz sampel bata. Penentuan kekuatan mampatan bata dilakukan pada orientasi muka katil dan umumnya bata konvensional hanya melakukan ujian bagi orientasi muka katil. Bata dikenakan daya mampatan yang sekata pada kadar $15 \mathrm{Nmm}^{-2}$. Kadar pembebanan boleh ditingkatkan beransur-ansur namun tidak melebihi $35 \mathrm{Nmm}^{-2}$ hingga setengah daripada beban maksimum yang dijangkakan (BS EN 772-1 2011). Kemudian, nilai pembebanan diturunkan kepada $15 \mathrm{Nmm}^{-2}$ sehingga bata mengalami kegagalan. Pembenanan akan secara automatik berhenti apabila bata gagal dan nilai beban maksimum, $F_{m a k}$ direkodkan. Maka kekuatan mampatan bata, $U C S_{\text {mak }}$ dihitung berdasarkan kepada nisbah antara $F_{\max }$ dan luas muka katil bata, $A$ seperti yang ditunjukkan oleh (6).

$$
\text { Kekuatan maksimum, } U C S_{\text {mak }}=F_{\max } /_{A}
$$

\section{HASIL DAN PERBINCANGAN}

\section{UJIAN LARUTRESAP}

Penentuan kelarutresapan unsur logam berat yang hadir dalam bata telah dilakukan di makmal bermula hari pertama hingga hari ke-60. Hasil daripada ujian larutresap bagi ketiga-tiga jenis sampel bata yang terdiri daripada bata tanpa bakar dan dibakar pada suhu 350 dan 700 ${ }^{\circ} \mathrm{C}$ ditunjukkan dalam Jadual 2(a), 2(b) dan 2(c). Nilai kepekatan logam berat yang ditentukan dibandingkan dengan piawaian oleh USEPA (1996).

Sampel bata tanpa bakar menunjukkan kehadiran logam berat yang terdiri daripada unsur $\mathrm{Al}, \mathrm{As}, \mathrm{Cd}, \mathrm{Cr}$, $\mathrm{Cu}, \mathrm{Pb}, \mathrm{Ni}, \mathrm{Zn}$ dan Fe. Kepekatan unsur bagi Al, Zn dan 
Fe adalah antara yang tinggi berbanding unsur lain pada hari pertama, masing-masing dengan nilai kepekatan $0.0185,0.0270$ dan $0.1106 \mathrm{mgL}^{-1}$, manakala unsur $\mathrm{Cd}$ dan $\mathrm{Pb}$ adalah antara yang terendah diperhatikan sepanjang tempoh cerapan ini (Jadual 2(a)). Kepekatan unsur logam berat lain juga menunjukkan corak perubahan kepekatan yang sama, namun kesemua nilai yang ditunjukkan berada di bawah tahap kepekatan yang disenaraikan oleh USEPA (1996).

JADUAL 2a. Corak perubahan nilai kepekatan unsur logam berat dalam sampel bata yang dihasilkan tanpa bakar (TB)

\begin{tabular}{|c|c|c|c|c|c|c|c|c|}
\hline \multirow{3}{*}{$\begin{array}{l}\text { Logam } \\
\text { berat }\end{array}$} & \multirow{3}{*}{$\begin{array}{c}\text { Tahap } \\
\text { kepekatan } \\
(\mathrm{mg} / \mathrm{L})^{*}\end{array}$} & \multicolumn{7}{|c|}{ Tempoh (Hari) } \\
\hline & & 1 & 3 & 7 & 14 & 21 & 30 & 60 \\
\hline & & \multicolumn{7}{|c|}{ Kepekatan (mg/L) } \\
\hline $\mathrm{Al}$ & $0.05-0.2$ & 0.0185 & 0.0218 & 0.0234 & 0.0232 & 0.0223 & 0.0229 & 0.0173 \\
\hline As & 5 & 0.0026 & 0.0041 & 0.0028 & 0.0040 & 0.0042 & 0.0027 & 0.0041 \\
\hline $\mathrm{Cd}$ & 1 & 0.0000 & 0.0000 & 0.0000 & 0.0000 & 0.0001 & 0.0000 & 0.0000 \\
\hline $\mathrm{Cr}$ & 5 & 0.0031 & 0.0030 & 0.0025 & 0.0026 & 0.0027 & 0.0028 & 0.0031 \\
\hline $\mathrm{Cu}$ & 100 & 0.0044 & 0.0034 & 0.0019 & 0.0023 & 0.0026 & 0.0014 & 0.0017 \\
\hline $\mathrm{Pb}$ & 5 & 0.0001 & 0.0000 & 0.0000 & 0.0005 & 0.0000 & 0.0001 & 0.0000 \\
\hline $\mathrm{Ni}$ & 1.34 & 0.0073 & 0.0025 & 0.0014 & 0.0014 & 0.0016 & 0.0013 & 0.0011 \\
\hline $\mathrm{Zn}$ & 500 & 0.0270 & 0.0197 & 0.0141 & 0.0216 & 0.0177 & 0.0219 & 0.0158 \\
\hline $\mathrm{Fe}$ & 0.30 & 0.1106 & 0.0981 & 0.0847 & 0.0863 & 0.0952 & 0.1035 & 0.0884 \\
\hline
\end{tabular}

* United States Protection Agency (USEPA 1996)

Sampel bata yang dirawat pada suhu $350{ }^{\circ} \mathrm{C}$ menunjukkan unsur logam $\mathrm{Al}, \mathrm{Cr}, \mathrm{Zn}$ dan Fe yang tinggi pada hari pertama berbanding unsur lain, masing-masing memberikan nilai $0.0110,0.0674,0.0585$ dan 0.0630 $\mathrm{mgL}^{-1}$ (Jadual 2(b)). Unsur Cd dan $\mathrm{Pb}$ juga menunjukkan kepekatan yang terendah. Corak kepekatan ini juga ditunjukkan oleh sampel bata yang dirawat pada suhu 350 dan $700{ }^{\circ} \mathrm{C}$. Kesan suhu ke atas bata yang dihasilkan menunjukkan peningkatan kepekatan unsur logam Al, $\mathrm{Cr}$, Ni dan Zn sebaliknya bagi unsur Fe berbanding bata tanpa bakar (Jadual 2(b) dan 2(c)). Namun demikian, kenaikan ini masih berada di bawah tahap yang dibenarkan oleh USEPA (1996). Pada peringkat akhir cerapan, jelas menunjukkan kepekatan unsur logam $\mathrm{Al}, \mathrm{Cr}$, Ni dan $\mathrm{Zn}$ berada dalam julat yang dibenarkan. Unsur logam lain turut menunjukkan penyusutan nilai kepekatan sepanjang tempoh cerapan ini. Secara keseluruhannya, hasil analisis ini menunjukkan unsur logam yang dilepaskan daripada sampel bata yang dikaji berada dalam julat piawaian yang dibenarkan mengikut USEPA. 
JADUAL 2(b). Corak perubahan nilai kepekatan unsur logam berat dalam sampel bata pada suhu $350{ }^{\circ} \mathrm{C}$

\begin{tabular}{|c|c|c|c|c|c|c|c|c|}
\hline \multirow{3}{*}{$\begin{array}{l}\text { Logam } \\
\text { berat }\end{array}$} & \multirow{3}{*}{$\begin{array}{c}\text { Tahap } \\
\text { kepekatan } \\
(\mathrm{mg} / \mathrm{L})^{*}\end{array}$} & \multicolumn{7}{|c|}{ Tempoh (Hari) } \\
\hline & & 1 & 3 & 7 & 14 & 21 & 30 & 60 \\
\hline & & \multicolumn{7}{|c|}{ Kepekatan (mg/L) } \\
\hline $\mathrm{Al}$ & $0.05-0.2$ & 0.0110 & 0.0122 & 0.0616 & 0.0579 & 0.0451 & 0.0401 & 0.0038 \\
\hline As & 5 & 0.0014 & 0.0023 & 0.0069 & 0.0074 & 0.0064 & 0.0057 & 0.0039 \\
\hline $\mathrm{Cd}$ & 1 & 0.0001 & 0.0000 & 0.0000 & 0.0000 & 0.0000 & 0.0000 & 0.0000 \\
\hline $\mathrm{Cr}$ & 5 & 0.0674 & 0.0187 & 0.0079 & 0.0029 & 0.0026 & 0.0019 & 0.0030 \\
\hline $\mathrm{Cu}$ & 100 & 0.0018 & 0.0021 & 0.0048 & 0.0011 & 0.0020 & 0.0019 & 0.0021 \\
\hline $\mathrm{Pb}$ & 5 & 0.0003 & 0.0003 & 0.0003 & 0.0001 & 0.0000 & 0.0000 & 0.0001 \\
\hline $\mathrm{Ni}$ & 1.34 & 0.0034 & 0.0014 & 0.0013 & 0.0008 & 0.0012 & 0.0013 & 0.0016 \\
\hline $\mathrm{Zn}$ & 500 & 0.0585 & 0.0308 & 0.0382 & 0.0300 & 0.0201 & 0.0200 & 0.0180 \\
\hline $\mathrm{Fe}$ & 0.30 & 0.0630 & 0.0206 & 0.0635 & 0.0456 & 0.0739 & 0.0577 & 0.0577 \\
\hline
\end{tabular}

* United States Protection Agency (USEPA 1996)

JADUAL 2(c). Corak perubahan nilai kepekatan unsur logam berat dalam sampel bata pada suhu $700{ }^{\circ} \mathrm{C}$

\begin{tabular}{|c|c|c|c|c|c|c|c|c|}
\hline \multirow{3}{*}{$\begin{array}{c}\text { Logam } \\
\text { berat }\end{array}$} & \multirow{3}{*}{$\begin{array}{c}\text { Tahap } \\
\text { kepekatan } \\
(\mathrm{mg} / \mathrm{L})^{*}\end{array}$} & \multicolumn{7}{|c|}{ Tempoh (Hari) } \\
\hline & & 1 & 3 & 7 & 14 & 21 & 30 & 60 \\
\hline & & \multicolumn{7}{|c|}{ Kepekatan (mg/L) } \\
\hline $\mathrm{Al}$ & $0.05-0.2$ & 0.0215 & 0.0235 & 0.0783 & 0.0693 & 0.0654 & 0.0638 & 0.0568 \\
\hline As & 5 & 0.0053 & 0.0088 & 0.0136 & 0.0143 & 0.0116 & 0.0098 & 0.0049 \\
\hline $\mathrm{Cd}$ & 1 & 0.0003 & 0.0001 & 0.0001 & 0.0001 & 0.0001 & 0.0001 & 0.0001 \\
\hline $\mathrm{Cr}$ & 5 & 0.0943 & 0.0163 & 0.0048 & 0.0027 & 0.0021 & 0.0016 & 0.0025 \\
\hline $\mathrm{Cu}$ & 100 & 0.0020 & 0.0029 & 0.0103 & 0.0021 & 0.0017 & 0.0018 & 0.0015 \\
\hline $\mathrm{Pb}$ & 5 & 0.0000 & 0.0001 & 0.0000 & 0.0001 & 0.0000 & 0.0000 & 0.0006 \\
\hline $\mathrm{Ni}$ & 1.34 & 0.0028 & 0.0012 & 0.0018 & 0.0012 & 0.0012 & 0.0011 & 0.0011 \\
\hline $\mathrm{Zn}$ & 500 & 0.0692 & 0.0416 & 0.0671 & 0.0413 & 0.0364 & 0.0361 & 0.0322 \\
\hline $\mathrm{Fe}$ & 0.30 & 0.0729 & 0.0195 & 0.0603 & 0.0620 & 0.0508 & 0.0381 & 0.0334 \\
\hline
\end{tabular}

* United States Protection Agency (USEPA 1996) 


\section{PENGECUTAN LINEAR}

Pengecutan akibat daripada proses pengeringan dan pembakaran memberikan kesan terhadap isipadu akhir bata yang dihasilkan. Hasil daripada penentuan dimensi setiap sampel bata, plot perubahan isipadu (\%) bagi set bata yang dihasilkan adalah ditunjukkan oleh Rajah 2 . Berdasarkan pemerhatian ini, terdapat perhubungan antara pengaruh suhu dan perubahan isipadu sampel bata yang dihasilkan. Penyusutan isipadu membenarkan penyejatan air berlaku melalui proses pengeringan melibatkan suhu berjulat antara 20 hingga $150{ }^{\circ} \mathrm{C}$ (Ahmari \& Zhang 2012; Diop et al. 2011). Secara umumnya, semakin tinggi suhu yang dikenakan, semakin tinggi perubahan isipadu yang berlaku ke atas kedua-dua jenis sampel bata (Jadual 3). Namun secara perbandingan, sampel bata RAM100 menyusut lebih tinggi berbanding sampel bata RAM80 jika dirawat pada suhu bilik (TB) dan suhu $350{ }^{\circ} \mathrm{C}$ iaitu masing-masing 13.14 dan $6.15 \%$. Ini dikaitkan oleh kesan daripada pemusnahan sebahagian daripada kandungan organik yang hadir (Akinshipe \& Kornellus 2017). Pada suhu $350{ }^{\circ} \mathrm{C}$ juga mengakibatkan air yang terikat secara molekul pada mineral liat mula dibebaskan (Johari et al. 2010). Pada suhu rawatan $700{ }^{\circ} \mathrm{C}$, sampel bata RAM80 pula menunjukkan peningkatan yang tinggi berbanding sampel bata RAM100 (Jadual 3). Kehadiran 20\% sisa abu terbang dalam campuran bata ini memberi kesan kepada peningkatan perubahan isipadu sampel bata. Berdasarkan kajian Choudhury (2015) ke atas bata liat turut menunjukkan kesan peningkatan pengecutan linear akibat daripada peningkatan sisa abu terbang. Sukkae et al. (2018) turut mendapati peningkatan pengecutan linear bagi bata dengan campuran 10 dan $20 \%$ abu terbang namun pada suhu lebih tinggi daripada $1250{ }^{\circ} \mathrm{C}$, nilai pengecutan linear mulai berkurangan. Penggunaan suhu yang terlalu tinggi perlu dielakkan dari perspektif kos dan kesan kepada alam sekitar.

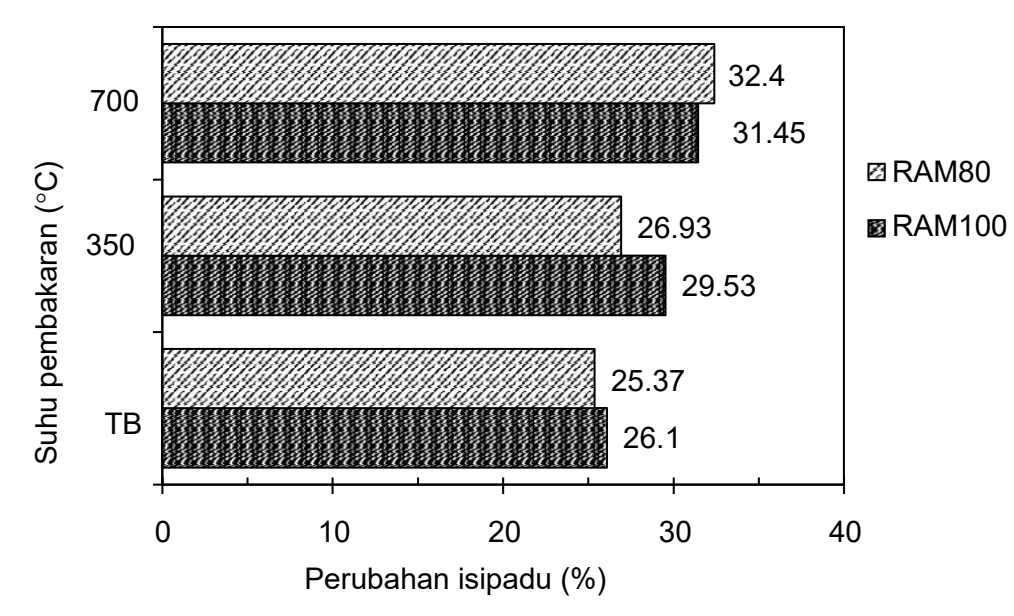

RAJAH 2. Pengaruh suhu terhadap perubahan isipadu bagi sampel bata

JADUAL 3. Peningkatan penyusutan isipadu bagi bata yang dihasilkan berdasarkan perubahan suhu

\begin{tabular}{lcc}
\hline \multirow{2}{*}{ Jenis bata } & \multicolumn{2}{c}{ Penyusutan isipadu, \% } \\
\cline { 2 - 3 } & $\mathrm{TB} \rightarrow 350{ }^{\circ} \mathrm{C}$ & $350{ }^{\circ} \mathrm{C} \rightarrow 700{ }^{\circ} \mathrm{C}$ \\
\hline RAM100 & 13.14 & 6.50 \\
RAM80 & 6.15 & 20.31 \\
\hline
\end{tabular}




\section{SERAPAN AIR}

Serapan air oleh bata perlu ditentukan bagi menilai sampel bata yang disediakan hasil daripada campuran sisa yang digunakan. Kesan perawatan suhu terhadap bata boleh mempengaruhi parameter ini. Kualiti yang baik sepatutnya mempunyai keresapan air yang rendah bagi menjamin ketahanannya terhadap persekitaran (Ali Rahman et al. 2019). Berdasarkan ujian parameter, jelas menunjukkan kesan kenaikan suhu telah meningkatkan penyerapan air bagi kedua-dua jenis sampel bata yang dihasilkan (Rajah 3). Secara perbandingan, sampel bata RAM100 menunjukkan serapan air yang lebih tinggi daripada sampel bata RAM80. Keadaan ini dikaitkan dengan keliangan terbuka yang ditinggalkan hasil daripada pemusnahan bahan organik akibat proses pembakaran (Fungaro \& Silva 2014). Ini dapat diperhatikan pada sampel RAM100 yang menunjukkan perkaitan serapan air dengan peningkatan suhu yang dikenakan. Manakala diperhatikan bagi sampel bata RAM80, corak yang sama didapati namun lebih rendah berbanding sampel bata RAM100. Ini dapat dijelaskan oleh kehadiran bahan organik yang rendah di dalam sampel AT berbanding sisa RAM (Jadual 1). Ini disebabkan oleh kandungan sisa RAM dikurangkan dalam sampel bata RAM80, maka pembentukan rongga terbuka bagi sampel hasil pembakaran bahan organik pada suhu tinggi adalah lebih rendah berbanding sampel bata RAM100. Keupayaan serapan air bata dijangka menyusut sekiranya penggunaan suhu pembakaran yang lebih tinggi dikenakan. Ini disebabkan proses vitrifikasi (pengacaan) terhadap mineral seperti silika dan aluminium, membentuk amorfus mengakibatkan serapan air menyusut dengan ketara (Karaman et al. 2006). Kehadiran amorfus tersebut turut membantu meningkatkan kekuatan bahan konkrit (Davraz \& Gunduz 2005). Namun terdapat faktor lain yang turut dipertimbangkan dengan kehadiran unsur yang meruwap menyebabkan keliangan bata meningkat dan seterusnya menyebabkan nilai ketumpatan turut menyusut (Abdul \& Mohajerani 2013).

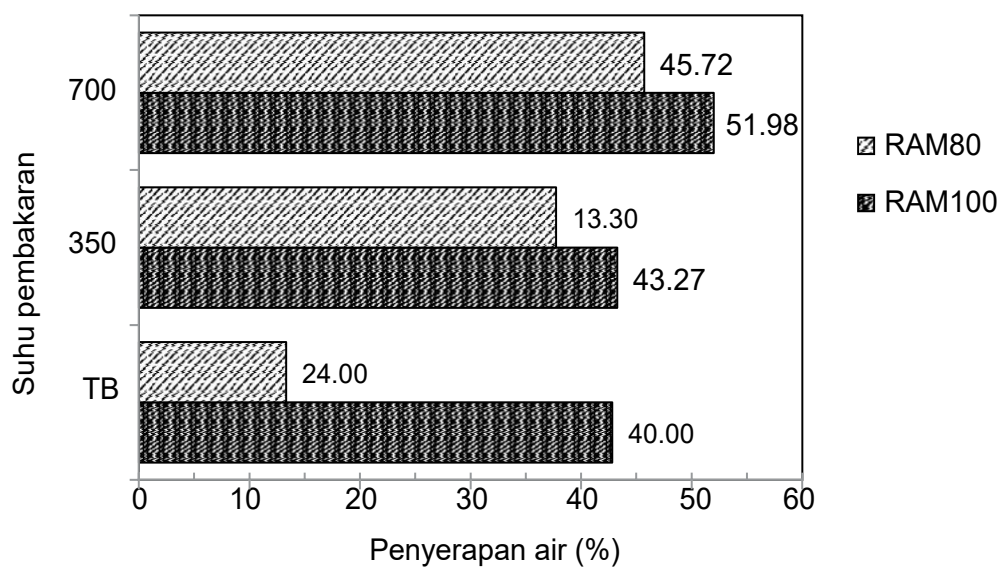

RAJAH 3. Pengaruh suhu terhadap ciri serapan air bagi sampel bata

\section{KETUMPATAN}

Ujian penentuan ketumpatan bata dilakukan bagi melihat perbezaan ketumpatan bata yang telah dihasilkan mengikut pengaruh suhu yang berbeza. Umumnya, bata yang dihasilkan akan mengalami perubahan ketumpatan antara 1300 dan $2200 \mathrm{kgm}^{-3}$ (Arman Ali 2005). Peningkatan suhu semasa pembakaran pada suhu berbeza menyebabkan nilai ketumpatan bata berubah (Abdul \& Maohajerani
2013). Berdasarkan kajian Naganathan et al. (2012), didapati bahawa ketumpatan bata berasaskan tanah campuran abu terbang dan simen hanya mencapai julat ketumpatan antara 1.5 dan $1.7 \mathrm{gcm}^{-3}$. Kesan penambahan abu terbang hanya memberikan kesan yang minimum terhadap ketumpatan sesuatu bata (Waridi 2014).

Hasil daripada penentuan nilai ketumpatan membuktikan bahawa ketumpatan yang berbeza bergantung kepada suhu yang berbeza. Rajah 4 
menunjukkan corak perubahan nilai ketumpatan bata terhadap suhu yang dikenakan. Perubahan ketumpatan bagi sampel tanpa bakar (TB) kepada jenis sampel yang dirawat pada suhu $350^{\circ} \mathrm{C}$ adalah lebih tinggi bagi sampel bata RAM100 (12.66\%) berbanding sampel bata RAM80 (3.35\%). Namun demikian, ketumpatan sampel bata menunjukkan peningkatan semula pada suhu pembakaran $700^{\circ} \mathrm{C}$ bagi kedua-dua jenis bata. Penyusutan ketumpatan pada suhu $300^{\circ} \mathrm{C}$ dapat dikaitkan dengan hasil serapan air yang meningkat dengan peningkatan suhu pembakaran (Rajah 3). Penyerapan air yang tinggi dikaitkan dengan kehadiran rongga yang banyak dalam bata hasil daripada pemusnahan bahan organik dan turut mengakibatkan penyusutan ketumpatan bata (Lin \& Weng 2001; Mageed et al. 2011; Weng et al. 2003). Manakala peningkatan semula ketumpatan pada suhu $700{ }^{\circ} \mathrm{C}$ boleh dikaitkan dengan perubahan struktur mineral dan pengisian semula sebahagian rongga yang hadir dalam bata (Karaman et al. 2006). Namun dari perspektif berbeza, penurunan ketumpatan bata memberikan kelebihan dalam sektor pembinaan dari aspek pengendalian dan pemasangan bata jenis ini (Abdul \& Mohajerani 2013). Hasil kajian ini dapat digunakan sebagai asas kepada pembangunan bata jenis ketumpatan rendah berasaskan gabungan sisa-sisa yang digunakan.

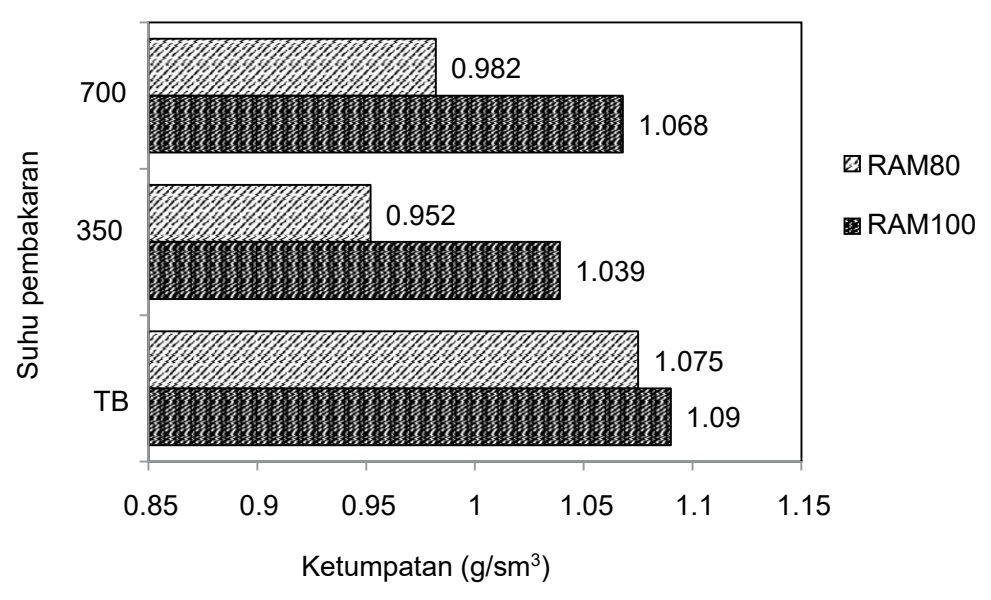

RAJAH 4. Pengaruh suhu terhadap ketumpatan bagi sampel bata

\section{KEKUATAN MAMPATAN}

Kekuatan mampatan sampel adalah penting bagi mengukur keupayaan bata terhadap beban yang dikenakan bagi memenuhi piawaian yang perlu dalam aplikasi kejuruteraan (Ramadan et al. 2008). Suhu yang dikenakan ke atas bata mempengaruhi kekuatan mekanik bata. Bata konvensional dibakar pada suhu yang sangat tinggi sekitar 900 hingga $1200^{\circ} \mathrm{C}$ dan mampu menghasilkan bata dengan kekuatan mampatan tertentu (Hiwot et al. 2017; Tsega et al. 2017).

Hasil penentuan kekuatan mampatan ke atas keduadua jenis bata ditunjukkan oleh Rajah 5. Berdasarkan rajah tersebut, didapati kekuatan mampatan sampel bata yang dikaji menunjukkan peningkatan selaras dengan suhu yang dikenakan. Sampel bata RAM100 menunjukkan nilai kekuatan mampatan yang lebih tinggi berbanding bata RAM80. Sungguhpun sisa AT dapat meningkatkan kualiti mekanik bat, namun nilai kekuatan mampatan masih rendah daripada sampel RAM100. Corak perubahan peningkatan kekuatan mampatan bagi jenis bata adalah berbeza berdasarkan tahap suhu pembakaran yang dikenakan (Jadual 4). Sampel bata RAM80 menunjukkan peningkatan ketara nilai kekuatan mampatan daripada tahap tanpa bakar (TB) ke tahap $350{ }^{\circ} \mathrm{C}$ dan $700{ }^{\circ} \mathrm{C}$ jika dibandingkan sampel bata RAM100. Sungguhpun dari segi nilai maksimum kekuatan mekanik yang dicapai 
ditunjukkan oleh bata RAM100, namun perubahan yang berlaku akibat perubahan tahap suhu adalah jelas diperhatikan bagi sampel RAM80. Perubahan yang ketara bagi kedua-dua sampel bata berlaku apabila bata mengalami peningkatan suhu dari 350 kepada $700{ }^{\circ} \mathrm{C}$. Ini menjelaskan pengaruh suhu penting dalam memainkan peranan dalam meningkatkan kualiti mekanik sesuatu bata.

Kajian oleh Krishnan dan Jewaratnam (2017) mendapati pengaruh suhu terhadap kekuatan mampatan namun kekuatan maksimum dihadkan oleh kandungan sisa RAM yang digunakan. Berdasarkan kajian, mereka mendapati bahawa campuran sisa melebihi $40 \%$ menunjukkan corak kekuatan mampatan yang menyusut. Perubahan kimia terhadap komposisi liat dalam sampel bata bermula seawal suhu $600{ }^{\circ} \mathrm{C}$ yang bertanggungjawab meningkatkan kekuatan mampatan. Peningkatan suhu kepada $700{ }^{\circ} \mathrm{C}$ mempertingkat perubahan kimia dalam sampel bata. Menurut Johari et al. (2010), proses dehidroksilasi berlaku dalam mineral liat dan kesan fluks ke atas $\mathrm{K}_{2} \mathrm{O}, \mathrm{Na}_{2} \mathrm{O}$ dan $\mathrm{CaO}$ bermula apabila mineral mencapai suhu $900{ }^{\circ} \mathrm{C}$. Proses vetrifikasi bertanggungjawab dalam pembentukan ikatan atom antara zarah oleh kristal kekaca membentuk struktur yang lebih padat. Anyokora (2013) turut menunjukkan hubungan linear positif antara suhu pembakaran dan kualiti mekanik bagi bata liat campuran sisa rawatan air (SRA). Namun kesan peningkatan nisbah campuran SRA menyebabkan nilai ketumpatan maksimum menyusut yang boleh dikaitkan oleh kehadiran silika yang rendah berbanding liat.

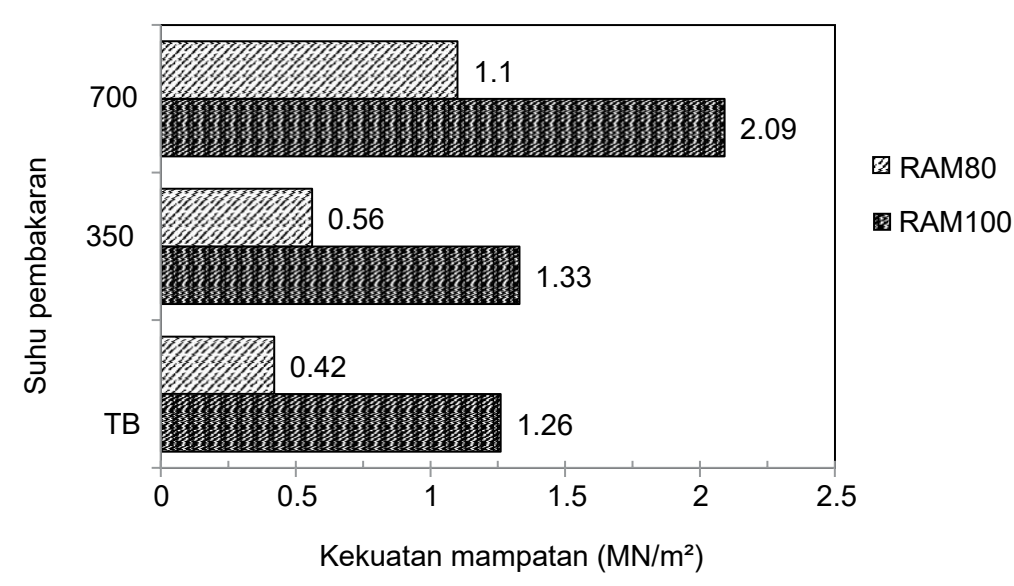

RAJAH 5. Pengaruh suhu terhadap kekuatan mampatan bagi sampel bata

JADUAL 4. Peningkatan kekuatan mampatan bagi bata yang dihasilkan berdasarkan perubahan suhu

\begin{tabular}{lcc}
\hline \multirow{2}{*}{ Jenis bata } & \multicolumn{2}{c}{ Peningkatan kekuatan mampatan, $\%$} \\
\cline { 2 - 3 } & $\mathrm{TB} \rightarrow 350{ }^{\circ} \mathrm{C}$ & $350{ }^{\circ} \mathrm{C} \rightarrow 700{ }^{\circ} \mathrm{C}$ \\
\hline RAM100 & 5.26 & 57.14 \\
RAM80 & 33.33 & 96.43 \\
\hline
\end{tabular}




\section{KESIMPULAN}

Berdasarkan ujian kelarutresapan logam berat ke atas sampel bata menunjukkan unsur logam yang dilepaskan daripada sampel bata yang dikaji berada dalam julat piawaian yang dibenarkan mengikut USEPA. Manakala hasil penentuan parameter mekanik bata yang dikaji menunjukkan bahawa bata berasaskan sisa rawatan air dan campuran sisa abu terbang dipengaruhi oleh suhu yang dikenakan semasa proses pembakaran. Umumnya, suhu pembakaran mempengaruhi penyusutan linear bagi kedua-dua jenis bata. Namun terdapat peningkatan nilai penyusutan linear kesan daripada penambahan sisa abu terbang (RAM80) berbanding bata berasaskan sepenuhnya sisa rawatan air (RAM100) apabila suhu pembakaran ditingkatkan kepada suhu lebih tinggi $\left(700^{\circ} \mathrm{C}\right)$. Serapan air turut meningkat bagi kedua-dua jenis bata namun bata sisa rawatan air campuran abu terbang (RAM80) menunjukkan pengurangan serapan air berbanding bata RAM100 dengan peningkatan suhu pembakaran. Pengaruh suhu pembakaran turut mempengaruhi ketumpatan bata yang dikaji, namun kenaikan suhu yang lebih tinggi mengakibatkan nilai ketumpatan bata meningkat semula dan ini dikaitkan dengan perubahan struktur mineral yang lebih padat dan pengisian ruang rongga yang hadir dalam sampel bata. Peningkatan suhu memberikan kesan menggalakkan kepada kekuatan mampatan bata yang dikaji. Kesan penambahan sisa abu terbang pada nisbah 20\% (RAM80) tidak mampu menghasilkan kekuatan bata yang diharapkan berbanding bata berasaskan sisa rawatan air sepenuhnya (RAM100). Berdasarkan hasil penentuan larutresap ini dan hasil pencirian mekanik yang dilakukan, sisa rawatan air dan abu terbang berpotensi digunakan sebagai bahan asas dalam pembangunan bata dan beberapa pengubahsuaian diperlukan bagi mencapai piawaian yang diperlukan sebagai bahan binaan alternatif.

\section{PENGHARGAAN}

Penulis ingin mengucapkan setinggi-tinggi terima kasih untuk geran penyelidikan ETP-2015-003 \& GUP-2016-068 atas pembiayaan sehingga penyelidikan ini diselesaikan. Setinggi-tinggi terima kasih juga kepada kakitangan makmal di Makmal Kejuruteraan Awam, Fakulti Kejuruteraan dan Alam Bina UKM atas penyediaan dan pengujian sampel.

\section{RUJUKAN}

Abdul, A.K. \& Mohajerani, A. 2013. Physical and mechanical properties of fired clay bricks incorporated with cigarette butts: Comparison between slow and fast heating rates. Applied Mechanics and Materials 421: 201-204.
Ahmari, S. \& Zhang, L. 2012. Production of eco-friendly bricks from copper mine tailings through geopolymerization. Construction and Building Materials 29: 323-331.

Akinshipe, O. \& Kornellus, G. 2017. Chemical and thermodynamic processes in clay brick firing technologies and associated atmospheric emissions metrics - A review. Journal of Pollution Effects \& Control 5(2): 1-12.

Ali Rahman, Z., Hamid, N.M., Rahim, S.A., Idris, W.M.R. \& Lihan, T. 2016. Pencirian mekanikal bata daripada campuran sisa rawatan air (DWS) dan abu terbang (FA) (Mechanical characterization of brick from mixture of water treatment sludege and rice ash ash).In Proceedings National Geoscience Conference.

Ali Rahman, Z., Mohd Saleh, N.S., Idris, W.M.R. \& Lihan, T. 2019. Thermal effect on mechanical characteristics of drinking water sludge brick incorporated with rice husk ash. Sains Malaysiana 48(11): 2541-2549.

Anyakora, N.V. 2013. Characterisation and performance evaluation of water works sludge as brickmaterial. International Journal of Engineering and Applied Sciences 3(3): 69-79.

Anyakora, N.V., Ajinomoh, C.S., Ahmed, A.S., MohammedDabo, I.A., Ibrahim, J. \& Anto, J.B. 2012. Sustainable technology-based strategy for processing water works sludge for resource utilization. World Journal of Engineering and Pure and Applied Sciences 2(5): 161-168.

ANSI/AN-16.1-2003 (American Nuclear Society). Measurement of the Leachability of Solidified Low-Level Radioactive Wastes by a Short-Term Test Procedure, Illinois.

Arman Ali, Z. 2005. Properties of Malaysian fired clay bricks and their evaluation with international Masonry specifications - a case study. PhD Thesis. Universiti Teknologi Malaysia (tidak diterbitkan).

Chen, Y., Zhang, Y., Chen, T., Zhao, Y. \& Bao, S. 2011. Preparation of eco-friendly MS76 construction bricks from hematite tailings. Construction and Building Materials 25(4): 2107-2111.

Chiang, K.Y., Chou, P.H., Chien, K.L., Chen, J.L. \& Wu, C.C. 2009. Novel lightweight building bricks manufactured from water treatment plant sludge and agricultural waste. Journal of Residuals Science \& Technology 6(4): 185-191.

Davraz, M. \& Gunduz, L. 2005. Engineering properties of amorphous silica as a new natural pozzolan for use in concrete. Cement and Concrete Research 35(7): 1251-1261.

Diop, M.B., Grutzeck, M.W. \& Molez, L. 2011. Comparing the performances of bricks made with natural clay and clay activated by calcination and addition of sodium silicate. Applied Clay Sciences 54(2): 172-178.

Fungaro, D.A. \& da Silva, M.V. 2014. Utilization of water treatment plant sludge and coal fly ash in brick manufacturing. American Journal of Environmental Protection 2(5): 83-88.

Hegazy, B.E.E., Fouad, H.A. \& Hassanain, A.M. 2012. Incorporation of water sludge, silica fume and rice husk ash in brick making. Advances in Environmental Research 1(1): 83-96. 
Hiwot, M.G., Quezon, E.T. \& Kebede, G. 2017. Comparative study on compressive strength of locally produced fired clay bricks and stabilized clay bricks with cement and lime. Global Scientific Journal 5(12): 147-157.

Jabatan Perangkaan Malaysia 2019. Anggaran Penduduk Semasa 2018-2019. Saiz dan Pertumbuhan Penduduk. Ketua Perangkaan Malaysia, Jabatan Perangkaan Malaysia, JPM. https://www.dosm.gov.my.

Johari, I., Said, S., Hisham, B., Bakar, A. \& Ahmad, Z.A. 2010. Effect of the change of firing temperature on microstructure and physical properties of clay bricks from Beruas (Malaysia). Science of Sintering 42(2): 245-254.

Joshi, S. \& Shrivastava, K. 2011. Recovery of alum coagulant from water treatment plant sludge: A greener approach for water purification. International Journal of Advanced Computer Research 1(2): 101-103.

Karaman, S., Ersahin, S. \& Gunal, H. 2006. Firing temperature and firing time influence on mechanical and physical properties of clay bricks. Journal of Scientific \& Industrial Research 65: 153-159.

Krishnan, P. \& Jewaratnam, J. 2017. Recovery of water treatment residue into clay bricks. Chemical Engineering Transactions 56: 1837-1842.

Madurwar, M.V., Ralegaonkar, R.V. \& Mandavgane, S.A. 2013. Application of agro-waste for sustainable construction materials: A review. Construction and Building Materials 38(1): 872-878.

Mageed, A.A., Rizk, S.H. \& Abu-Ali, M.H. 2011. Utilization of water treatment plants sludge ash in brick making. Journal of Engineering Sciences 39(1): 195-206.

Prabakar, J. Dendorkar, N. \& Morchhale, R.K. 2004. Influence of fly ash on strength behavior of typical soils. Construction and Building Materials 18(4): 263-267.

Presertsan, S. \& Theppaya, T. 1995. A study towards energy saving in brick making: Part 1 Keyparameters for energy saving. International Energy Journal 17(2): 145-156.

Puppala, A.J. \& Musenda, C. 2000. Effects of fiber reinforcement on strength and volume change in expansive soils. Transportation Research Record 1736(1): 134-140.
Riza, F.V., Rahman, I.A. \& Ahmad Zaidi, A.M. 2010. A brief review of compressed stabilized earth brick (CSEB). In International Conference on Science and Social Research.

Sanga, P., Iradukunda, Y. \& Munyemana, J.C. 2018. Recycling of alum from water treatment residue and reuse it as a flocculating agent for raw water treatment. Journal of Geoscience and Environment Protection 6(12): 216-226.

Sukkae, R., Suebthawilkul, S. \& Cherdhirunkorn, B. 2018. Utilization of coal fly ash as a raw material for refractory production. Journal of Metals, Materials \& Minerals 28(1): 116-123.

Tantawy, M.A. \& Mohamed, R.S. 2017. Middle Eocene clay from Goset Abu Khashier: Geological assessment and utilization with drinking water treatment sludge in brick manufacture. Applied Clay Science 138: 114-124.

Tsega, E., Mosisa, A. \& Fufa, F. 2017. Effects of firing time and temperature on physical properties of fired clay bricks. American Journal of Civil Engineering 5(1): 21-26.

USEPA. 1996. Hazardous Waste Characteristics Scoping Study. US Environmental Protection Agency, Office of Solid Waste.

Wang, S.D., Scrivener, K.L. \& Pratt, P.L. 1994. Factors affecting the strength of alkali-activated slag. Cement and Concrete Research 24(6): 1033-1043.

Xu, L., Wei, G., Tao, W. \& Yang, N. 2005. Study on fired bricks with replacing clay by fly ash in high volume ratio. Construction and Building Materials 19(3): 243-247.

Zhang, L. 2013. Production of bricks from waste materials - A review. Construction and Building Materials 1(47): 643-655.

Pusat Sains Bumi dan Alam Sekitar

Fakulti Sains dan Teknologi

Universiti Kebangsaan Malaysia

43600 UKM Bangi, Selangor Darul Ehsan

Malaysia

*Pengarang untuk surat-menyurat; email: zarah1970@ukm. edu.my

Diserahkan: 11 Mei 2020

Diterima: 8 Oktober 2020 